\title{
ANALISIS KONTRAK KERJA DI KANTOR NOTARIS: TINJAUAN UNDANG-UNDANG NOMOR 13 TAHUN 2003 TENTANG KETENAGAKERJAAN
}

\author{
Zaenal Efendi, Mahasiswa Fakultas Hukum Universitas Islam Balitar, Blitar, E-mail: \\ zaenalefendisg@gmail.com;
}

Weppy Susetiyo, Dosen Fakultas Hukum, Universitas Islam Balitar, Blitar, E-mail: weppy_s@yahoo.co.id

\begin{abstract}
Abstrak
Notaris dalam menjalankan kewenangan dan kewajibannya sangat memerlukan bantuan tenaga kerja yang dalam hal ini adalah pekerja/karyawan notaris. Hubungan kerja antara Notaris sebagai pemberi kerja dengan pekerja timbul berdasarkan kontrak/perjanjian kerja. Ada dua jenis kontrak kerja yaitu perjanjian kerja untuk waktu tertentu (PKWT), dan perjanjian kerja waktu untuk tidak tertentu (PKWTT). Masing-masing bentuk perjanjian/kontrak kerja akan menimbulkan akibat hukum yang berbeda.

Field research di kantor Notaris Sulin, S.H., M.Kn. Kota Blitar, Jawa Timur dilengkapi dengan library research menghasilkan penelitian bahwa bentuk kontrak kerja di kantor Notaris Sulin, S.H., M.Kn. Blitar adalah perjanjian kerja waktu tidak tertentu yang hanya menggunakan karyawan tetap, dengan pelaksanaan dan penerapannya sesuai dengan amanah Undang-Undang Nomor 13 Tahun 2003 tentang Ketenagakerjaan.
\end{abstract}

Kata kunci: Kontrak Kerja, Kantor Notaris, Undang-Undang Nomor 13 Tahun 2003 tentang Ketenagakerjaan

\section{PENDAHULUAN}

\section{Latar Belakang}

Notaris adalah pejabat yang diangkat oleh pemerintah yang memperoleh kewenangan secara atributif dari Negara. Notaris bertindak untuk melayani kebutuhan masyarakat dalam hubungan hukum. Dalam pelayanannya Notaris terikat pada peraturan jabatan dan kode etik profesi sebagai Notaris. Dengan adanya kode etik dan peraturan jabatan, maka Notaris terikat dalam satu peraturan yang memuat kaidah moral dan sanksi-sanksi yang akan diberikan bila Notaris melakukan pelanggaran. Di dalam konsiderans menimbang huruf c, Undang-Undang Jabatan Notaris Nomor 2 Tahun 2014 tentang Jabatan Notaris (selanjutnya disebut UUJN), menyatakan bahwa Notaris merupakan jabatan tertentu yang menjalankan profesi dalam pelayanan hukum kepada masyarakat. ${ }^{1}$ Dengan demikian eksistensi Notaris bukanlah untuk kepentingan dirinya sendiri, tetapi untuk memenuhi kebutuhan masyarakat yang memerlukan pelayanan hukum. Inilah yang menjadi dasar Notaris harus senantiasa menambah pengetahuan, pengalaman dan keterampilan dalam melayani masyarakat sebagai misi utamanya. ${ }^{2}$

Keberhasilan seorang Notaris tidak lepas dari kepiawaiannya mengatur administrasi di kantornya. Hasil akta yang banyak tanpa disertai dengan administrasi yang rapi dan teratur pasti akan mengakibatkan masalah dan kesulitan di kemudian hari. Oleh karena itu perlu bagi seorang Notaris untuk mempelajari dan memperhatikan administrasi kantor. Administrasi dalam Notaris dapat diartikan sebagai kegiatan yang bersifat tulis menulis. seperti menulis daftar akta, dañar surat di bawah tangan yang disahkan, dañar

\footnotetext{
${ }^{1}$ Undang-Undang Republik Indonesia Nomor 2 Tahun 2014 tentang Jabatan Notaris.

${ }^{2}$ Lalu Husni, Hukum Ketenagakerjaan, Rajawali Press, 2009.
} 
surat dibawah tangan yang dibukukan dan lain-lain. Administrasi juga dapat diartikan sebagai manajemen, perencanaan, perorganisasian,, pengarahan, pengkoordinasian dan pengawasan pekerjaan ketatausahaan. sehingga dapat menyediakan informasi yang tepat dan bermanfaat. Hal-hal yang harus diperhatikan agar sebuah kantor Notaris dapat melaksanakn seluruh kegiatan dan aktivitasnya meliputi unsur kantor, inventaris atau peralatan kantor, karyawan, dan pendokumentasian atau tata kearsiapan.

Notaris dalam menjalankan kewenangan dan kewajibannya tersebut di atas, sangat memerlukan bantuan tenaga kerja yang dalam hal ini adalah pekerja/karyawan notaris. Karyawan Notaris memegang peran yang cukup penting untuk membantu kinerja Notaris dalam melayani jasa pembuatan akta, seperti membantu menyiapkan pembuatan, melakukan pendaftaran dan mengesahkan surat-surat atau akta-akta yang dibuat di bawah tangan dan menjadi saksi dalam peresmian akta.

Karyawan atau yang juga sering disebut pekerja merupakan elemen penting bagi Notaris dari segi tugas dan tanggung jawab yang diembannya, karena memiliki kedudukan strategis dalam proses pembuatan akta, tanpa karyawan apa yang telah dirancang oleh Notaris tentu tidak akan dapat terlaksana sesuai dengan perencanaan. Karena itu maka keberadaan pekerja atau karyawan harus diperhatikan supaya dapat menjalankan perintah notaris dengan baik.

Dalam konteks ini, seorang Notaris merupakan si pemberi kerja. Berdasarkan Pasal 1 angka 4 Undang-Undang Nomor 13 Tahun 2003 tentang Ketenagakerjaan (selanjutnya disebut UUK), pemberi kerja adalah orang perseorangan, pengusaha, badan hukum, atau badan-badan lainnya yang mempekerjakan tenaga kerja dengan membayar upah atau imbalan dalam bentuk lain. ${ }^{3}$ Sebagai orang perseorangan, seorang Notaris juga memerlukan pekerja sebagai penunjang profesional kerjanya. Tanpa pekerja, Notaris tidak dapat melaksanakan profesinya dengan cepat atau tepat waktu. Notaris selalu menitikberatkan pencarian pekerja yang minimal lulusan pendidikan Sekolah Menegah Atas (SMA), bagi Notaris lulusan SMA akan lebih mempunyai semangat kerja yang tinggi sehingga dapat diberikan gaji atau upah yang lebih rendah dibandingkan pekerja lulusan sarjana.

Pekerja Notaris memiliki potensi yang besar untuk menjalankan aktivitas seorang Notaris. Notaris dan pekerja merupakan dua hal yang saling membutuhkan. Bagi pekerja, keberhasilan merupakan aktualisasi potensi diri sekaligus peluang untuk memenuhi kebutuhan hidupnya sedangkan bagi Notaris, keberhasilan merupakan sarana menuju pertumbuhan dan perkembangan kesuksesan seorang Notaris. Sehingga kemampuan dan keterampilan serta keahlian karyawan Notaris perlu terus menerus ditingkatkan, baik melalui perencanaan maupun program pelatihan dan pemagangan yang lebih luas agar mampu dalam membantu kerja Notaris secara optimal.

Dalam dunia pekerjaan antara pemberi kerja (Notaris) dengan karyawannya, diawali dengan adanya hubungan hukum. Hubungan hukum adalah hubungan antara subjek hukum ataupun antara subjek hukum dengan objek hukum, yang diatur oleh hukum dan menimbulkan akibat hukum yaitu hak dan kewajiban. ${ }^{4}$ Setiap hubungan hukum yang diciptakan oleh hukum selalu mempunyai dua sisi. Sisi yang satu ialah hak dan sisi

\footnotetext{
${ }^{3}$ Undang-Undang Republik Indonesia Nomor 13 Tahun 2003 tentang Ketenagakerjaan.

${ }^{4}$ Marwan Mas, Pengantar Ilmu Hukum, Jakarta: Ghalia Indonesia, 2004, hlm. 40.
} 
lainnya adalah kewajiban, karena pada hakikatnya sesuatu pasti ada pasangannya, tidak ada hak tanpa kewajiban atau sebaliknya menyalahgunakan hak dianggap ada, apabila orang menjalankan haknya tidak sesuai dengan tujuan. Ada prestasi yang harus dilaksanakan oleh kedua belah pihak ini. Pemenuhan segala prestasi ini yang akan menimbulkan keharmonisasian ataupun disharmonisasi dalam hubungan kerja.

Hubungan hukum antara Notaris sebagai pemberi kerja dengan pekerja merupakan hubungan kerja. Secara garis besar hubungan kerja yaitu hubungan yang meliputi hak dan kewajiban antara pekerja dan pemberi kerja, terjadi setelah diadakan perjanjian oleh pekerja dengan pemberi kerja (perjanjian kerja). Menurut Pasal 1 angka 14 UUK, perjanjian kerja adalah perjanjian antara pekerja/buruh dengan pengusaha atau pemberi kerja yang memuat syarat-syarat kerja, hak dan kewajiban para pihak. Lebih jelasnya lagi, perjanjian kerja adalah perjanjian antara pekerja dengan pemberi kerja/pengusaha yang memuat syarat-syarat kerja, hak dan kewajiban para pihak mulai dari saat hubungan kerja itu terjadi hingga berakhirnya hubungan kerja. Dalam perjanjian kerja juga harus jelas memuat apakah hubungan kerja tersebut termasuk hubungan kerja untuk waktu tertentu (PKWT) atau untuk waktu tidak tertentu (PKWTT). ${ }^{5}$ Dari dua jenis kontrak kerja ini, UUK melarang mempekerjakan pekerja kontrak dengan perjanjian secara lisan. Untuk mempekerjakan pekerja kontrak, kontrak kerjanya harus dibuat secara tertulis. Jika kontrak kerjanya dibuat secara lisan, maka konsekuensinya PKWT berubah menjadi PKWTT dan dengan demikian pekerja kontrak yang bersangkutan menjadi pekerja tetap dengan segala hak-haknya. UUK melarang pengusaha menerapkan masa percobaan untuk pekerja kontrak yang hubungan kerjanya dibuat berdasarkan PKWT. Jika pengusaha menerapkan masa percobaan untuk pekerja kontrak, maka PKWT tersebut berubah menjadi PKWTT. ${ }^{6}$

Terjalinnya hubungan kerja antara Notaris dan pekerjanya seharusnya dimulai dengan perjanjian kerja. Sehingga syarat-syarat kerja, hak dan kewajiban para pihak jelas. Jika terjadi pelanggaran mengenai hal yang telah diperjanjikan maka sudah ada yang mengikat para pihak untuk bertanggung jawab.

Hubungan kerja merupakan hubungan saling ketergantungan antara pengusaha dan pekerja. Secara yuridis, Pasal 1 angka 15 UUK merumuskan hubungan kerja adalah hubungan antara pemberi kerja dengan pekerja/buruh berdasarkan perjanjian kerja, yang mengandung adanya unsur pekerjaan, upah, dan perintah.

UUK mengatur tentang segala hal yang berhubungan dengan tenaga kerja baik pada sebelum, selama dan sesudah masa kerja. Dimana dalam pelaksanaannya timbul akibat adanya perjanjian kerja. Tenaga kerja dalam konteks ini adalah setiap orang yang mampu melakukan pekerjaan guna menghasilkan barang dan atau jasa baik untuk memenuhi kebutuhan sendiri maupun untuk masyarakat. ${ }^{7}$

Dalam UUK pekerja atau buruh adalah setiap orang yang bekerja dengan menerima upah atau Imbalan dalam bentuk lain. ${ }^{8}$ Hubungan hukum yang terjadi antara pekerja dan pemberi kerja adalah sebagaimana substansi perjanjian kerja antara keduanya, yaitu

\footnotetext{
${ }^{5}$ Libertus Jehani S.H., M.H., Hak-Hak Karyawan Kontrak, Jakarta: Forum Sahabat, 2008, hlm. 5.

${ }^{6}$ Ibid., hlm. 6.

${ }^{7}$ Pasal 1 angka 2 Undang-Undang Ketenagakerjaan

${ }^{8}$ pasal 1 ayat 3
} 
perjanjian antara pekerja atau buruh dengan pengusaha atau pemberi kerja yang memuat syarat-syarat kerja hak dan kewajiban para pihak. ${ }^{9}$

Hak dan kewajiban antara pemberi kerja dengan pekerja baru akan ada setelah dibuat suatu perjanjian kerja seperti yang dimaksud dalam pasal 1 angka 15 UUK tersebut. Dengan demikian bila seseorang telah mengikatkan diri dalam suatu perjanjian kerja, berarti secara pribadi otomatis harus bersedia bekerja di bawah perintah orang lain. Akibat hukum yang timbul dari suatu perjanjian kerja adalah adanya suatu hubungan kerja, yaitu hubungan antara pengusaha dengan pekerja atau buruh berdasarkan perjanjian kerja yang mempunyai unsur pekerjaan upah dan perintah. ${ }^{10}$

Unsur-unsur yang menentukan adanya hubungan kerja, yaitu:

1. Adanya pekerjaan yang harus dilakukan

2. Adanya perintah (bekerja atas perintah atasan atau pengusaha)

3. Adanya upah

Tanpa adanya salah satu dari ketiga unsur tersebut maka tidak ada hubungan kerja.

Dalam pasal 50 UUK dijelaskan bahwa hubungan kerja terjadi karena adanya perjanjian kerja antara pengusaha dan pekerja/buruhnya. Sehingga jelas bahwa hubungan kerja baru ada setelah adanya perjanjian kerja. Perjanjian kerja termasuk ke dalam hukum yang bersifat otonom, artinya hukum yang mempunyai kedudukan dan peran yang sangat penting dan menentukan mengenai hak dan kewajiban kedua belah pihak serta menentukan penyelenggaraan hubungan kerja, putusnya hubungan kerja, serta pasca hubungan kerja. Dengan adanya perjanjian kerja diharapkan para pengusaha/majikan tidak lagi dapat memperlakukan para pekerja dengan sewenangwenang, karena di dalam perjanjian kerja diletakkan segala hak dan kewajiban secara timbal balik antara pengusaha dan pekerja. Perjanjian kerja dapat dibuat baik secara tertulis maupan secara lisan. Secara sosiologis, karyawan merupakan pihak yang lebih lemah dibanding pihak pemberi kerja. Pekerja atau karyawan adalah orang yang tidak bebas dalam menentukan kehendaknya terhadap pemberi kerja, karena dalam suatu hubungan kerja pemberi kerja telah memberikan batasan-batasan yang harus diikuti oleh pihak pekerja atau karyawan. ${ }^{11}$

Berdasarkan uraian yang telah terkemukakan di atas, maka peneliti tertarik untuk melakukan penelitian mengenai bentuk kontrak kerja di kantor notaris, dengan mengangkat permasalahan sebagai berikut :

1. Bagaimana bentuk kontrak kerja di Kantor Notaris Sulin, S.H., M.Kn. Blitar?

2. Bagaimana analisis kontrak kerja di Kantor Notaris ditinjau dari Undang-Undang Nomor 13 Tahun 2003 tentang Ketenagakerjaan?

\section{PEMBAHASAN}

\section{BENTUK KONTRAK KERJA DI KANTOR NOTARIS SULIN, S.H., M.KN. BLITAR}

Notaris sebagai pejabat yang bertindak melalui dua macam peranan (roles), yakni:

a. Selaku pelaku hukum publik (public actor) yang menjalankan kekuasaan publik (public authority, openbaar gezag), yang dijelmakan dalam kualitas penguasa (authorities) seperti

\footnotetext{
${ }^{9}$ pasal 1 angka 15 Undang-Undang Ketenagakerjaan

${ }_{10}$ pasal 1 angka 15 UUK

${ }^{11}$ Peraturan Pemerintah Republik Indonesia Nomor 78 Tahun 2015 tentang Pengupahan.
} 
halnya badan-badan tata usaha negara dan pelbagai jabatan yang diserahi wewenang penggunaan kekuasaan publik;

b. Selaku pelaku hukum keperdataan (civil actor) yang melakukan pelbagai perbuatan hukum keperdataan (privaatechtelijke handeling), seperti halnya mengikat perjanjian jual beli, sewa menyewa, pemborongan dan sebagainya, yang dijelmakan dalam kualitas badan hukum (legal person, rechtspersoon). ${ }^{12}$

Notaris Sulin, S.H., M.Kn. Blitar tidak hanya sekedar menjalankan kekuasaan dan wewenang hukum publik, akan tetapi Notaris Sulin, S.H., M.Kn. Blitar juga melakukan perbuatan hukum keperdataan (privaatrechtelijke handeling) seperti halnya seorang warga (dalam arti manusia pribadi) yang dapat melakukan tindakan seperti yang telah dijelaskan diatas, termasuk dalam hal melakukan pengangkatan terhadap calon pekerja/karyawan Notaris Sulin, S.H., M.Kn. Blitar.

Penerimaan karyawan Notaris Sulin, S.H., M.Kn. Blitar dalam hal ini meliputi pengumuman adanya lowongan dibutuhkannya karyawan Notaris Sulin, S.H., M.Kn. Blitar yang sesuai dengan kriteria, mengadakan tes baik tertulis maupun lisan dalam bentuk wawancara. Terhadap calon karyawan Notaris Sulin, S.H., M.Kn. Blitar yang telah memenuhi kriteria dapat dilakukan pengangkatan oleh Notaris Sulin, S.H., M.Kn. Blitar dengan membuat perjanjian kerja.

Karyawan atau tenaga kerja atau buruh seperti yang tercantum dalam Trade Union and Labour Relation (Consolidation) Act 1992 adalah buruh atau tenaga kerja yang bekerja dibawah kontrak kerja (perjanjian kerja) sebagai buruh tetap, buruh atau tenaga kerja yang bekerja dibawah kontrak kerja personal dan secara ekonomi bergantung pada perusahaan. Pada dasarnya azas isi perjanjian merupakan kebebasan yang diserahkan kepada para pihak untuk menentukan. Akan tetapi dalam hal perjanjian kerja, khususnya dalam hal waktu kerja, undang-undang memberikan pembatasan tersendiri. Pembatasan ini dimaksudkan untuk melindungi pekerja, memberikan keamanan atas pekerjaan (job security) sebagaimana di dalam peraturan perundang-undangan dijelaskan bahwa suatu peraturan/perundang-undangan yang lebih rendah tidak boleh bertentangan dengan peraturan yang lebih tinggi.

Kontrak kerja di Kantor Notaris Sulin, S.H., M.Kn. Blitar dibuat berdasarkan hal-hal sebagai berikut:

1. Kesepakatan kedua belah pihak (Notaris Sulin, S.H., M.Kn. Blitar dan karyawan);

2. Kecakapan para pihak untuk melakukan perbuatan hukum;

3. Adanya pekerjaan yang diperjanjikan;

4. Pekerjaan yang diperjanjikan tersebut tidak bertentangan dengan ketertiban umum, kesusialaan, dan peraturan perundang-undangan yag berlaku.

Perjanjian kerja yang dibuat oleh Notaris Sulin, S.H., M.Kn. Blitar dan ditandatangani oleh kedua belah pihak dalam hal ini calon karyawan Notaris Sulin, S.H., M.Kn. Blitar dan Notaris Sulin, S.H., M.Kn. Blitar menjadi dasar hubungan industrial antara Notaris dan karyawan Notaris, yaitu suatu sistem hubungan yang terbentuk antara para pelaku dalam proses produksi barang dan/atau jasa yang terdiri dari unsur pengusaha,

${ }^{12}$ Philipus M. Hadjon, dkk., Pengantar Hukum Administrasi Indonesia; Introduction to the Indonesian Administrative Law, Yogyakarta: Gadjah Mada University Press, 2001, hlm. 165-166. 
pekerja/buruh, dan pemerintah yang didasarkan pada nilai-nilai Pancasila dan Undangundang Dasar Negara Republik Indonesia Tahun 1945.13

Penerimaan karyawan di kantor Notaris Sulin, S.H., M.Kn. Blitar termasuk dalam bidang hukum privat, dan perjanjian kerja yang telah dibuat menjadi dasar hubungan industrial bagi kedua belah pihak, yaitu antara Notaris Sulin, S.H., M.Kn. Blitar sebagai pengusaha dalam istilah UUK, dan pekerja/karyawan. Pengusaha adalah orang perseorangan, persekutuan, atau badan hukum yang menjalankan suatu perusahaan milik sendiri; orang perseorangan, persekutuan, atau badan hukum yang secara berdiri sendiri menjalankan perusahaan bukan miliknya; orang perseorangan, persekutuan, atau badan hukum yang berada di Indonesia mewakili perusahaan yang berkedudukan di luar wilayah Indonesia. ${ }^{14}$ Sedangkan pelaku usaha adalah setiap orang perorangan atau badan usaha, baik yang berbentuk badan hukum maupun bukan badan hukum yang didirikan dan berkedudukan atau melakukan kegiatan dalam wilayah hukum negara Republik Indonesia, baik sendiri maupun bersama-sama melalui perjanjian menyelenggarakan kegiatan usaha dalam berbagai bidang ekonomi" ${ }^{15}$

Hukum ketenagakerjaan merupakan peraturan-peraturan tertulis atau tidak tertulis yang mengatur seseorang mulai dari sebelum, selama, dan sesudah tenaga kerja berhubungan dalam ruang lingkup di bidang ketenagakerjaan dan apabila dilanggar dapat terkena sanksi perdata atau pidana termasuk lembaga-lembaga penyelenggara swasta yang terkait di bidang tenaga kerja. ${ }^{16}$

Hubungan antara pengusaha/majikan (Notaris Sulin, S.H., M.Kn. Blitar) dengan karyawan/pekerja di dalam melaksanakan hubungan kerja di kantor Notaris Sulin, S.H., M.Kn. Blitar terjalin harmonis sehingga mencapai peningkatan produktifitas dan kesejahteraan pekerja. Untuk itu, Notaris Sulin, S.H., M.Kn. Blitar dalam menghadapi para karyawan menerapkan hal sebagai berikut:

a. Menganggap para karyawan sebagai partner yang akan membantunya untuk menyukseskan tujuan usaha;

b. Memberikan imbalan yang layak terhadap jasa-jasa yang telah dikerahkan oleh partnernya itu, berupa penghasilan yang layak dan jaminan-jaminan sosial tertentu, agar dengan demikian pekerja tersebut dapat bekerja lebih produktif (berdaya guna); dan

c. Menjalin hubungan baik dengan para pekerjanya. ${ }^{17}$

Keberhasilan Notaris Sulin, S.H., M.Kn. Blitar tidak hanya bisa diukur dari banyaknya akta yang Notaris Sulin, S.H., M.Kn. Blitar buat, melainkan juga dari kepiawaian mengatur administrasi di kantornya. Akta yang banyak, tanpa disertai administrasi yang rapi dan teratur akan mengakibatkan masalah dan kesulitan dikemudian hari. Oleh karena itu keberadaan karyawan di Notaris Sulin, S.H., M.Kn. Blitar sangat penting.

\footnotetext{
${ }^{13}$ Pasal 1 angka 14 UU Ketenagakerjaan

${ }^{14}$ Pasal 1 angka 5 UUK

${ }^{15}$ Pasal 1 angka 3 UU Nomor 8 Tahun 1999 tentang Perlindungan Konsumen

${ }^{16}$ G.H.S. Lumban Tobing, Peraturan Jabatan Notaris, Jakarta: Erlangga, 1983, hlm. 31.

${ }^{17}$ Lihat YW. Sunindhia dan Ninik Widayanti, Masalah PHK dan Pemogokan, Jakarta: Bina Aksara, 1998, hlm. 129.
} 
Kehadiran UUK menjawab akan kebutuhan tersebut. UUK merupakan pokok dasar hukum dalam pembuatan peraturan-peraturan kepegawaian dalam suatu perusahaan. UUK ini bisa dikatakan sebagai kompilasi dari ketentuan Hukum Ketenagakerjaan Indonesia, sehingga memudahkan para pihak yang berkepentingan (steakholders) untuk mempelajarinya. ${ }^{18}$ Dengan berlakunya undang-undang ini beberapa ketentuan peraturan perundang-undangan peninggalan Belanda dan perundang-undangan nasional dinyatakan tidak berlaku lagi.

Adapun pihak-pihak dalam hukum ketenagakerjaan menurut UUK antara lain adalah:

a. Buruh/Pekerja (Pasal 1 angka 3):

b. Pengusaha (Pasal 1 angka 5)

c. Organisasi Buruh/Pekerja

d. Organisasi Pengusaha

e. Pemerintah/Penguasa.

Berdasarkan UUK, peraturan kepegawaian dalam suatu perusahaan mencakup: Peraturan Perusahaan, Perjanjian Kerja Bersama dan Perjanjian Kerja. Berdasarkan UUK jelas bahwa hubungan kerja terjadi karena adanya perjanjian kerja antara pengusaha dan pekerja/buruh. Terkait dengan status pekerja, Pasal 50 UUK menentukan bahwa hubungan kerja terjadi karena adanya perjanjian kerja antara pengusaha dan pekerja/buruh. Lebih lanjut diuraikan dalam Pasal 51 sampai dengan Pasal 61 UUK berikut ini.

Perjanjian kerja dibuat secara tertulis atau lisan, dibuat atas dasar :

a. kesepakatan kedua belah pihak;

b. kemampuan atau kecakapan melakukan perbuatan hukum;

c. adanya pekerjaan yang diperjanjikan; dan

d. pekerjaan yang diperjanjikan tidak bertentangan dengan ketertiban umum, kesusilaan, dan peraturan perundang undangan yang berlaku.

Segala hal dan/atau biaya yang diperlukan bagi pelaksanaan pembuatan perjanjian kerja dilaksanakan oleh dan menjadi tanggung jawab pengusaha. Perjanjian kerja yang dibuat secara tertulis sekurang kurangnya memuat:

a. nama, alamat perusahaan, dan jenis usaha;

b. nama, jenis kelamin, umur, dan alamat pekerja/buruh;

c. jabatan atau jenis pekerjaan;

d. tempat pekerjaan;

e. besarnya upah dan cara pembayarannya;

f. syarat syarat kerja yang memuat hak dan kewajiban pengusaha dan pekerja/buruh;

g. mulai dan jangka waktu berlakunya perjanjian kerja;

h. tempat dan tanggal perjanjian kerja dibuat; dan

i. tanda tangan para pihak dalam perjanjian kerja.

Ketentuan besarnya upah dan cara pembayarannya dan syarat syarat kerja yang memuat hak dan kewajiban pengusaha dan pekerja/buruh; tidak boleh bertentangan dengan peraturan perusahaan, perjanjian kerja bersama, dan peraturan perundang undangan

${ }^{18}$ Lalu Husni, Op.Cit, hlm. 24. 
yang berlaku. Perjanjian kerja dibuat sekurang kurangnya rangkap 2 (dua), yang mempunyai kekuatan hukum yang sama, serta pekerja/buruh dan pengusaha masing masing mendapat 1 (satu) perjanjian kerja. Perjanjian kerja tidak dapat ditarik kembali dan/atau diubah, kecuali atas persetujuan para pihak. Perjanjian kerja dibuat untuk waktu tertentu atau untuk waktu tidak tertentu.

Perjanjian kerja untuk waktu tertentu (PKWT) didasarkan atas jangka waktu atau selesainya suatu pekerjaan tertentu, dibuat secara tertulis serta harus menggunakan bahasa Indonesia dan huruf latin. PKWT yang dibuat tidak tertulis dinyatakan sebagai perjanjian kerja untuk waktu tidak tertentu (PKWTT). Dalam hal perjanjian kerja dibuat dalam bahasa Indonesia dan bahasa asing, apabila kemudian terdapat perbedaan penafsiran antara keduanya, maka yang berlaku perjanjian kerja yang dibuat dalam bahasa Indonesia. PKWT tidak dapat mensyaratkan adanya masa percobaan kerja. Jika tetap dalam perjanjian kerja, maka masa percobaan kerja yang disyaratkan batal demi hukum. PKWT hanya dapat dibuat untuk pekerjaan tertentu yang menurut jenis dan sifat atau kegiatan pekerjaannya akan selesai dalam waktu tertentu, yaitu:

a. pekerjaan yang sekali selesai atau yang sementara sifatnya;

b. pekerjaan yang diperkirakan penyelesaiannya dalam waktu yang tidak terlalu lama dan paling lama 3 (tiga) tahun;

c. pekerjaan yang bersifat musiman; atau

d. pekerjaan yang berhubungan dengan produk baru, kegiatan baru, atau produk tambahan yang masih dalam percobaan atau penjajakan.

PKWT tidak dapat diadakan untuk pekerjaan yang bersifat tetap. PKWT yang didasarkan atas jangka waktu tertentu dapat diadakan untuk paling lama 2 (dua) tahun dan hanya boleh diperpanjang 1 (satu) kali untuk jangka waktu paling lama 1 (satu) tahun. Pembaruan PKWT hanya dapat diadakan setelah melebihi masa tenggang waktu 30 (tiga puluh) hari berakhirnya PKWT yang lama, pembaruan PKWT ini hanya boleh dilakukan 1 (satu) kali dan paling lama 2 (dua) tahun. PKWT yang tidak memenuhi ketentuan UUK, maka demi hukum menjadi perjanjian kerja waktu tidak tertentu (PKWTT).

Dari penjabaran di atas, jelas diketahui ada dua jenis perjanjian/kontrak kerja yakni:

a. perjanjian kerja untuk waktu tertentu (PKWT), yang lazim digunakan untuk mempekerjakan pekerja kontrak; dan

b. perjanjian kerja waktu untuk tidak tertentu (PKWTT). PKWTT lazim digunakan untuk mempekerjakan pekerja tetap. ${ }^{19}$

Hasil penelitian tentang perjanjian kerja di kantor Notaris Sulin, S.H., M.Kn. Blitar menghasilkan hasil penelitian bahwa Notaris Sulin, S.H., M.Kn. Blitar memakai perjanjian kerja waktu tidak tertentu (PKWTT). Perjanjian kerja waktu tidak tertentu (PKWTT) merupakan perjanjian kerja yang tidak ditentukan waktunya dan bersifat tetap. ${ }^{20}$ Dengan berpedoman pada ketentuan pasal 59 ayat 7 UUK bahwa perjanjian kerja untuk waktu tertentu yang tidak memenuhi ketentuan sebagaimana dimaksud dalam ayat 1 , ayat 2 . ayat 4 , ayat 5 , dan ayat 6 maka demi hukum menjadi perjanjian kerja waktu tidak tertentu (PKWTT).

\footnotetext{
${ }^{19}$ Libertus Jehani S.H., M.H., Hak-Hak Karyawan Kontrak, Jakarta: Forum Sahabat, 2008, hlm. 6.

${ }^{20} \mathrm{http} / / /$ legalakses.com/perjanjian-kerja-untuk-waktu-tidak-tertentu-pkwtt/ , diakses pada $19 \mathrm{Juli}$ 2018.
} 
Penerapan bentuk kontrak kerja PKWTT di Kantor Notaris Sulin S.H., M.Kn. disebabkan karena pada kantor Notaris tersebut memang tidak menerapkan sistem kontrak perjanjian kerja waktu tertentu. Dengan kata lain kantor Notaris Sulin, S.H., M.Kn. Blitar hanya memiliki pekerja tetap yang terlebih dahulu juga melalui proses perjanjian kerja waktu tidak tertentu. Pada Undang-undang Ketenagakerjaan juga tidak mengharuskan kantor Notaris memiliki sistem perjanjian kerja waktu tertentu, sehingga pada kantor Notaris Sulin, S.H., M.Kn. Blitar hanya memiliki pekerja tetap dan tidak bertentangan dan UUK.

Bagi perjanjian kerja tidak dimintakan bentuk yang tertentu. Jadi biasa dilakukan dengan cara lisan, dengan surat pengangkatan oleh pihak pengusaha atau secara tertulis, yaitu surat perjanjian yang ditandatagani oleh kedua belah pihak. Undang-Undang hanya menetapkan bahwa jika perjanjian diadakan secara tertulis. Biaya surat dan biaya tambahan lainnya harus dipikul oleh pengusaha, yang mana surat pengangkatan tetap dibuat oleh perusahaan yang berisikan muatan singkat tentang hak dan kewajiban kedua belah pihak.

Lebih jelasnya lagi, pada pasal 1601 a KUHPerdata memberikan pengertian bahwa perjanjian kerja adalah suatu perjanjian dimana pihak ke-1(satu)/buruh atau pekerja mengikatkan dirinya untuk dibawah perintah pihak yang lain (majikan) untuk suatu waktu tertentu melakukan pekerjaan dengan menerima upah.

Menyimak dari pengertian perjanjian kerja menurut KUHPerdata, bahwa ciri khas perjanjian kerja adalah "adanya dibawah perintah pihak lain" sehingga tampak hubungan antara pekerja dan pengusaha adalah hubungan bawahan dan atasan, terlepas waktu yang diperjanjikan.

Dalam suatu perjanjian kerja juga harus ada pekerjaan yang diperjanjikan. Pekerjaan tersebut harus dilakukan sendiri oleh pekerja, hanya atas izin majikan pekerjaan tersebut boleh diwakilkan. Seperti halnya pada KUHPerdata pasal 1603 a: "buruh wajib melakukan sendiri pekerjaannya: hanya dengan seizin majikannya dapat menyuruh orang ketiga menggantikannya". Dengan demikian para karyawan kantor Notaris Sulin, S.H., M.Kn. Blitar memiliki pekerjaan masing-masing yang menunjang administrasi kantor Notaris Sulin, S.H., M.Kn. Blitar dan tidak boleh diwakilkan, tanpas seizin majikan (Notaris Sulin, M.Kn. S.H., Blitar). Pada perjanjian kerja di kantor Notaris Sulin, S.H., M.Kn. Blitar tersebut juga harus memenuhi syarat sahnya perjanjian sebagaimana diatur dalam pasal 1320 KUHPerdata yaitu untuk sahnya suatu perjanjian diperlukannya empat syarat sebagai berikut:21

1. Sepakat mereka yang mengikatkan dirinya:

2. Kecakapan untuk membuat suatu perikatan;

3. Suatu hal tertentu;

4. Suatu sebab yang halal.

Pada umumnya suatu perjanjian harus memenuhi syarat di atas. Sama halnya di kantor Notaris Sulin, S.H., M.Kn. Blitar sudah menerapkan syarat tersebut di atas dengan baik. Syarat-syarat tersebut memiliki sifat kumulatif, artinya harus dipenuhi semuanya agar dapat dikatakan bahwa perjanjian kerja tersebut sah. Syarat kemauan bebas kedua

${ }^{21}$ Kitab Undang-Undang Hukum Perdata. 
belah pihak dan kernampuan atau kecakapan kedua belah pihak dalam mebuat perjanjian dalam hukum perdata disebut sebagai syarat subjektif karena menyangkut menegnai orang yang membuat perjanjian, sedangkan syarat adanya pekerjaan yang diperjanjikan dan pekerjaan itu harus halai disebut sebagai syarat objektif karena menyangkut objek perjanjian. Kalau syarat itu objektif tidak terpenuhi, maka perjanjian itu batal demi hukum, artinya dan awal perjanjian tersebut dianggap tidak pernah ada. Jika yang tidak dipenuhi syarat subjektifnya, maka akibat hukum dan perjanjian tersebut dapat dibatalkan, pihak yang tidak memberikan persetujuan secara tidak bebas.

\section{ANALISIS KONTRAK KERJA DI KANTOR NOTARIS SULIN, S.H., M.KN. BLITAR DITINJAU DARI UNDANG-UNDANG NOMOR 13 TAHUN 2013 TENTANG KETENAGAKERJAAN}

Hubungan kerja antara pengusaha dengan pekerja didasarkan kontrak/perjanjian kerja yang disepakati oleh kedua belah pihak. Kontrak/ perjanjian kerja diatur dalam Bab IX Undang-Undang RI nomor 13 tahun 2003 tentang Ketenagakerjaan (UUK). Pengertian kontrak/perjanjian kerja sebagaimana diatur dalam UUK pasal 1 ayat 14 adalah perjanjian antara pekerja/buruh dengan pengusaha atau pembeni kerja yang memuat syarat-syarat kerja, serta hak dan kewajiban para pihak. Selanjutnya pada ayat 15 disebutkan bahwa hubungan kerja adalah hubungan antara pekerja dengan pengusaha berdasarkan perjanjian kerja, yang mempunyai unsur pekerjaan, upah dan perintah.

Kontrak kerja yang diterapkan pada kantor Notaris Sulin, S.H., M.Kn. Blitar adalah perjanjian kerja waktu tidak tertentu atau bisa disebut pegawai tetap, dengan memperhatikan dasar pertimbangan pemberlakuan UUK bahwa perlindungan terhadap tenaga kerja dimaksudkan untuk menjamin hak hak dasar pekerja/buruh dan menjamin kesamaan kesempatan serta perlakuan tanpa diskriminasi atas dasar apapun untuk mewujudkan kesejahteraan pekerja/buruh dan keluarganya dengan tetap memperhatikan perkembangan kemajuan dunia usaha.

Menurut pasal 60 ayat 1 UUK, Perjanjian Kerja Waktu Tidak Tertentu (PKWTT) atau permanen dapat mensyaratkan adanya masa percobaan paling lama tiga bulan. Oleh karena itu, masa kerja karyawan tetap di kantor notaris dihitung mulai sejak tanggal selesainya masa percobaan sebagaimana tercantum dalam perjanjian kerja sejak tanggal yang tertulis dalam surat pengangkatan bagi pekerja. Jangka waktu perjanjian kerja dapat dibuat untuk waktu tertentu bagi hubungan kerja yang dibatasi jangka waktu berlakunya, dan waktu tidak tertentu bagi hubungan kerja yang tidak dibatasi jangka waktu berlakunya atau selesainya pekerjaan tertentu. Perjanjian kerja yang dibuat untuk waktu tertentu biasa disebut dengan perjanjian kerja kontrak atau perjanjian kerja tidak tetap. Status pekerjanya adalah pekerja tidak tetap atau pekerja kontrak. Sedangkan untuk perjanjian kerja yang dibuat untuk waktu tidak tertentu biasanya disebut dengan perjanjian kerja tetap dan statusnya adalah pekerja tetap.

Pada kantor Notaris Sulin, S.H., M.Kn. Blitar tidak menerapkan sistem pekerja kontrak memang karena pada dasarnya menjadi karyawan Notaris Sulin, S.H., M.Kn. Blitar bukanlah pekerjaan yang cepat selesai dalam kurun waktu maksimal 3 tahun, yakni bukan termasuk pekerjaan yang sekali selesai dan predictible. Dalam pasal 59 ayat 1 UUK menyebutkan bahwa perjanjian kerja untuk waktu tertentu hanya dapat dibuat untuk 
pekerjaan tertentu yang menurut jenis dan sifatnya atau kegiatan pekerjaannya akan selesai dalam waktu tertentu, yaitu:

1. Pekerjaan yang sekali selesai atau yang sementara sifatnya;

2. Pekerjaan yang diperkirakan penyelesaiaannya dalam waktu tidak terlalu lama dan paling lama 3 (tiga) tahun:

3. Pekerjaan yang bersifat musiman; atau

4. Pekerjaan yang berhubungan dengan produk baru, kegiatan baru, atau produk tambahan yang masih dalam percobaan atau penjajakan.

Dari ketentuan tersebut di atas, tampak bahwa pengaturan tentang syarat-syarat mempekerjakan pekerja kontrak sangat dibatasi (limitatif). Berdasarkan ketentuan tersebut juga sudah jelas bahwa perjanjian kerja untuk waktu tertentu tidak dapat diadakan untuk pekerjaan yang bersifat tetap. Jadi pada dasarnya undang-undang ketenagakerjaan telah mengatur dan bahwasannya kantor Notaris Sulin, S.H., M.Kn. Blitar merupakan salah satu perusahaan atau kantor yang tidak bisa menerapkan sistem kontrak kerja karyawan.

Dalam praktek di kantor Notaris Sulin, S.H., M.Kn. Blitar juga terdapat perjanjian kerja tidak dibuat tertulis, bisa melalui lisan dengan prasyarat Notaris Sulin, S.H., M.Kn. Blitar wajib membuat surat pengangkatan bagi karyawan yang bersangkutan. Dijelaskan pada pasal 63 ayat 1 UUK yang berbunyi: "dalam hal perjanjian kerja waktu tidak tertentu dibuat secara usan. maka penusaha wajib membuat surat pengangkatan bagi pekerjalburuh yang bersangkutan". Jadi pada PKWTT tetap akan memiliki alat bukti yang sah terhadap perjanjian kerja walau perjanjian kerja itu dilakukan secara lisan. Dan status pekerja tetap tersebut terhitung sejak tanggal pengangkatan yang tertera pada surat pengangkatan.

Pada umumnya, kadang pekerja pada mulanya dipekerjakan sebagai pekerja dengan Perjanjian Kerja Waktu Tertentu (PKWT) atau bisa disebut pekerja dengan sistem kontrak dan kemudian oleh pengusaha dapat mensyaratkan pekerja tersebut untuk melalui masa percobaan sebelum diangkat menjadi pekerja tetap. Namun. pada kantor Notaris Sulin, S.H., M.Kn. Blitar tidak memiliki sistem pekerja kontrak seperti pada umumnya, disana hanya memiliki para pegawai tetap yang memang pada mulanya melalui masa percobaan dan kemudian diangkat sebagai pekerja tetap seperti yang diatur pada Undang-Undang Ketengakerjaan.

Untuk diketahui pula dalam hal terjadinya pemutusan hubungan kerja (PHK) pada PKWTT atau pekerja tetap berbeda dengan PKWT atau pekerja kontrak. Bila PWKT atau pekerja kontrak melakukan pemutusan hubungan kerja tercantum pada UUK pasal 62 yang berbunyi:

"apabila salah satu pihak mengakhiri hubungan kerja sebelum berkahirnya jangka waktu yang ditetapkan dalam perjanjian kerja waktu tertentu, atau berakhirnya hubungan kerja bukan karena ketentuan sebagaimana dimaksud dalam pasal 61 ayat 1, pihak yag mengakhiri hubungan kerja diwajibkan membayar ganti rugi kepada pihak lainnya sebesar upah pekerja/buruh sampai batas waktu berakhimya jangka waktu perjanjian kerja".

Sedangkan pada PKWTT yang ada di kantor notaris pemutusan hubungan kerja bisa dikarenakan pengunduran diri pekerja atas kemauan sendiri, dengan konsekuensi pekerja berhak juga mendapatkan uang penggantian hak dan uang pisah atau bisa 
disebut uang pesangon. Diatur pada pasal 162 ayat 1 dan ayat 2 UUK. Berbeda dengan PKWT, PWKTT ketika mengundurkan diri malah akan diberi uang pesangon, jika PWKT akan dikenakan ganti rugi seperti yang dijelaskan sebelumnya.

Istilah kontrak kerja dapat kita temui juga di dalam KUHPerdata bahkan di dalam ketentuan hukum tersebut memuat pula pengertian kontrak. Disamping itu istilah kontrak, kitab undang-undang juga menggunakan istilah perikatan. lstilah perjanjian dalam pasal 1313 KUHPerdata, didefinisikan sebagai suatu perbuatan dengan mana suatu orang atau lebih mengikatkan dirinya terhadap satu orang lain atau lebih".

Kita ketahui bahwa kontrak/perjanjian kerja pasti ada hubungan timbal balik yang selaras, antara pekerja dan pengusaha sama-sama membutuhkan. Hal tersebut tercantum pada pasal 1314 ayat 2 KUHPerdata yang berbunyi, "suatu perjanjian atas beban adalah suatu perjanjian yang mewajibkan masing-masing pihak memberikan sesuatu, berbuat sesuatu atau tidak berbuat sesuatu". Ada dua (2) jenis perjanjian. yaitu perjanjian sepihak dan perjanjian timbal balik, dan PKWTT ini tennasuk perjanjian timbal balik, termasuk PKWT. Perjanjian timbal balik ialah suatu perjanjian yang memberikan kewajiban dan hak pada kedua belah pihak.

KUHPerdata juga membahas tentang bagaimana sahnya perjanjian. Suatu kontrak/perjanjian dianggap sah dan mengikat, maka perjanjian tersebut harus memenuhi syarat-syarat tertentu. Syarat perjanjian diatur dalam pasal 1320 KUHPerdata yaitu:

1. Sepakat mereka yang mengikatkan dirinya.

Syarat pertama ini merupakan awal dan terbentuknya perjanjian, yaitu adanya kesepakatan antara pihak tentang isi perjanjian yang akan mereka laksanakan. Oleh karena itu terjadinya kata sepakat tidak boleh disebabkan oleh tiga hal, yaitu adanya unsur paksaan, penipuan dan kekeliruan. Apabila perjanjian tersebut dibuat berdasarkan adanya paksaan dan salah satu pihak, maka perjanjian tersebut dapat dibatalkan. Memandang dan perjanjian kerja di kantor notanis. kesepakatan dilaksanakan dengan baik dan sah.

2. Kecakapan untuk membuat suatu perikatan

Pada saat penyusunan kontrak/perjanjian, para pihak khususnya manusia secara hukum telah dewasa atau cakap berbuat atau belum dewasa tetapi ada walinya. Sedangkan para karyawan di kantor Notaris Sulin, S.H., M.Kn. Blitar memiliki ratarata usia dewasa karena di kantor Notaris Sulin, S.H., M.Kn. Blitar hanya memiliki karyawan tetap, menjadi hampir tidak ada karyawan yang masih usia remaja. Hal ini berarti, praktek kontrak kerja di Kantor Notaris Sulin, S.H., M.Kn. memang benarbenar menerapkan norma hukum UUK sebagaimana Pasal 68 UUK yang melarang mempekerjakan anak, yaitu setiap orang yang berumur di bawah 18 (delapan belas) tahun (Pasal 1 angka 28 UUK).

3. Mengenai suatu hal

Tertentu secara yuridis suatu perjanjian harus mengenai hal tertentu yang telah disetujui. Suatu hal tertentu disini adalah objek perjanjian dan isi perjanjian. Setiap perjanjian harus memiliki objek tertentu, jelas, dan tegas. Disini dalam perjanjian kerja di kantor Notaris Sulin, S.H., M.Kn. Blitar memiliki objek perjanjian dalam hal kerja yang melingkupi bekerja sebagai pelaksana administrasi kantor notaris. 


\section{Suatu sebab yang halal}

Setiap perjanjian yang dibuat para pihak tidak boleh bertentangan dengan undang-undang, ketertiban umum, dan kesusialaan. Dalam akta perjanjian sebab dan perjanjian. Perjanjian kerja pada kantor Notaris Sulin, S.H., M.Kn. Blitar sudah jelas halal dan sah karena telah berpedoman pada undang-undang dan peraturan yang berlaku.

Konsekuensi yuridis dari terbentuknya kontrak kerja yang sah di Kantor Notaris S.H., M.Kn. Blitar kontrak kerja tersebut mengikat antara Notaris S.H., M.Kn. sebagai pengusaha/pemberi kerja dan karyawan/pekerja, menjadikan para pihak wajib melaksanakan kontrak kerja dengan itikad baik dan tidak bisa memutuskan kotrak kerja tersebut secara sepihak. Sebagai konsekuensi dari sahnya kontrak kerja, Kantor Notaris S.H., M.Kn. Blitar sebagai pengusaha/pemberi kerja, wajib memberikan upah pekerja kepada karyawan-karyawannya serta tunjangan hari raya (THR).

Upah pekerja sebagai hak pekerja yang diterima dan dinyatakan dalam bentuk uang sebagai imbalan dari pengusaha/ pemberi kerja kepada pekerja yang ditetapkan dan dibayarkan menurut suatu perjanjian kerja, dengan aspek upah pekerja ${ }^{22}$ sebagai berikut:

1. Upah minimum;

2. Upah kerja lembur;

3. Upah tidak masuk kerja karena melakukan kegiatan lain diluar pekerjaannya;

4. Upah karena menjalankan hak waktu istirahat kerja;

5. Bentuk dan cara pembayaran upah;

6. Denda dan pemotongan upah;

7. Hal-hal yang dapat diperhitungkan dengan upah;

8. Struktur dan skala pengupahan yang proporsional;

9. Upah untuk pembayaran perseorangan;

10.Upah untuk penghitungan pajak penghasilan (PPh).

Upah minimum sebagai hak dasar setiap pekerja di Kantor Notaris S.H., M.Kn. Blitar dipenuhi dan dilaksanakan oleh Kantor Notaris S.H., M.Kn. Blitar, sebagai kewajibannya kepada setiap pekerja/karyawannya pada saat pekerja tersebut bekerja padanya.

Sebagai konsekuensi yuridis dari kontrak kerja yang telah sah antara Kantor Notaris S.H., M.Kn. Blitar dan pekerja/karyawannya, Kantor Notaris S.H., M.Kn. Blitar juga memberikan Tunjangan Hari Raya (THR) kepada setiap pekerja/karyawannya. THR adalah pendapatan pekerja yang wajib dibayarkan pengusaha kepada pekerja atau keluarganya menjelang hari raya keagamaan yang berupa uang atau bentuk lain. Hari Raya Idul Fitri bagi pekerja yang beragama Islam, Hari Raya Natal bagi pekerja yang beragama Katolik dan Protestan, Hari Raya Nyepi bagi pekerja yang beragama Hindu, dan Hari Raya Waisak bagi pekerj yang beragama Budha.

Pemberian THR oleh Kantor Notaris S.H., M.Kn. Blitar kepada setiap karyawannya yang dibagikan paling lambat 7 (tujuh) hari sebelum hari raya keagamaan dirayakan. Untuk pekerja uang sudah bekerja satu tahun atau lebih, minimal THR yang akan

${ }^{22}$ Libertus Jehani S.H., M.H., Hak-Hak Karyawan Kontrak, Jakarta: Forum Sahabat, 2008, hlm. 17. 
diterimanya adalah sebesar 1 bulan upah. Pemberian THR oleh Kantor Notaris S.H., M.Kn. Blitar kepada setiap karyawannya merupakan wujud pelaksanaan amanah peraturan perundang-undangan sebagaimana Peraturan Menteri Tenaga Kerja RI No. Per 104/MEN/1994 tentang Tunjangan Hari Raya keagamaan bagi Pekerja di Perusahaan, sebagai aturan turunan atau aturan pelaksanaan dari Undang-Undang Republik Indonesia Nomor 13 Tahun 2013 tentang Ketenagakerjaan. Lebih jauhnya lagi, tindakan yang dilakukan oleh Kantor Notaris S.H., M.Kn. Blitar terhadap para karyawannya tersebut di atas, mencerminkan pelaksanaan keadilan dalam konteks ketenagakerjaan. Yakni, memberikan kepada masing-masing apa yang menjadi haknya (to give everybody his own). ${ }^{23}$

\section{PENUTUP}

Bentuk kontrak kerja di kantor Notaris Sulin, S.H., M.Kn. Blitar yaitu perjanjian kerja waktu tidak tertentu yang hanya menggunakan karyawan tetap, tidak menggunakan sistem perjanjian kerja waktu tertentu karena kantor Notaris Sulin, S.H., M.Kn. Blitar tidak memenuhi prasyarat penerapan perjanjian waktu tertentu mempertimbangkan kantor Notaris Sulin, S.H., M.Kn. Blitar tidak memiliki jangka waktu pekerjaan yang panjang sebagaimana amanah pasal 59 ayat I Undang-Undang Nomor 13 Tahun 2003 tentang Ketenagkerjaan. Analisis kontrak kerja di Kantor Notaris Sulin, S.H., M.Kn. Blitar menurut Undang-Undang Ketenagakerjaan Nomor 13 Tahun 2003 menghasilkan kesimpulan bahwa penerapan kontrak kerja di Kantor Notaris Sulin, S.H., M.Kn. Blitar sesuai dengan Undang-Undang Nomor 13 Tahun 2003 tentang Ketenagakerjaan.

Perjanjian kerja merupakan dasar terjadinya hubungan kerja yang memuat hak dan kewajiban dan pihak buruh/pekerja maupun pihak pengusaha/pimpinan. Maka dalam pembuatan perjanjian kerja dan dalampelaksanaanya disarankan untuk:

1. Perjanjian kerja sebaiknya dibuat secara tertulis untuk lebih menjamin kepastian hukum, walaupun dalam Undang-Undang Ketenagakerjaan diperbolehkan untuk melakukan perjanjian kerja secara lisan.

2. Melakukan musyawarah/munfakat sebelum pembuatan yang kemudian hasilnya dituangkan secara jelas pada perjanjian kerja.

3. Dalam perjanjian kerja, sebaiknya ditentukan bagaimana mekanisme penyelesaianperselisihan apabila dalam pelaksanaan perjanjian kerja terjadi perbedaan pendapat antara pekerja dengan pengusaha.

\section{DAFTAR PUSTAKA}

\section{Jurnal dan Buku:}

Ade Saptomo, Pokok-pokok Metode Penelitian Hukum, Surabaya: Uness Universitas Press, 2007.

Amiruddin dan Zainal Asikin, Pengantar Metode Penelitian Hukum, Jakarta: PT. Raja Grafindo Persada, 2012.

Anshori, Abdul Ghofur, Lembaga Kenotariatan Indonesia Perspektif Hukum dan Etika, Cetakan kedua, Yogyakarta: UII Press, 2010.

${ }^{23}$ Definisi keadilan dalam perspektif para filosof barat. 
Anshori, Abdul Ghofur, Pokok-Pokok Umum Perjanjian Islam, Yogyakarta: Citra Media, 2006.

Bogdan dan Taylor dalam Moleong, Metode Penelitian Kualitatif, Bandung : Remaja Rosda Karya, 2000.

Erick N, Penelitian Mandiri Hukum Acara, Blitar, 2018.

G.H.S. Lumban Tobing, Peraturan Jabatan Notaris, Jakarta: Erlangga, 1983.

Ganang Dwi Cahyono, Suhariningsih, Prija, Implementasi Pemenuhan Hak Pekerja dalam Hal Upah di Kantor Notaris (Analisis Undang-Undang Nomor 13 Tahun 2003 Pasal 88-98 tentang Ketenagakerjaan), Program Studi Magister Kenotariatan Pasca Sarjana Fakultas Hukum Universitas Brawijaya.

Hadjon, Philipus M., dkk., Pengantar Hukum Administrasi Indonesia; Introduction to the Indonesian Administrative Law, Yogyakarta: Gadjah Mada University Press, 2001.

Husni, Lalu, Hukum Ketenagakerjaan, Rajawali Press, 2009.

Jehani S.H., M.H., Libertus, Hak-Hak Karyawan Kontrak, Jakarta: Forum Sahabat, 2008.

Mas, Marwan, Pengantar Ilmu Hukum, Jakarta: Ghalia Indonesia, 2004.

Muljadi, Kartini dan Widjaja, Gunawan, Perikatan yang Lahir dari Perjanjian, Jakarta: PT Raja Grafindo Persada, 2004.

Notodisoerjono, R. Soegondo, Hukum Notariat di Indonesia Suatu Penjelasan, Raja Grafindo Persada, Jakarta, 1993.

Peter Mahmud, Penelitian Hukum, Surabaya: Prenada, 2009.

Putri, Asrilia Bayi Saka; Gunarto, Perlindungan Hukum Karyawan Notaris Pada Perjanjian Kerja Waktu Tertentu (PKWT), Jurnal Kata Vol. 4 No. 4 Desember 2017.

R. Supomo, Hukum Acara Perdata Pengadilan Negeri, Jakarta: Pradnya Paramita.

Ratiba, Matome M., Convecaying Law for Paralegals and Law Students, bookboon.com, Pretoria, 2013.

Rianto, Adi, Metodologi Penelitian Sosial \& Hukum, Jakarta : Granit, 2004.

Salim HS, dalam Suharnoko, Hukum Perjanjian, Jakarta: Kencana, 2009.

Sunindhia, YW. dan Ninik Widayanti, Masalah PHK dan Pemogokan, Jakarta: Bina Aksara, 1998.

\section{Peraturan Perundang-Undangan:}

Kitab Undang-Undang Hukum Perdata.

Undang-Undang Nomor 13 Tahun 2003 tentang Ketenagakerjaan.

Undang-Undang Republik Indonesia Nomor 2 Tahun 2014 tentang Jabatan Notaris.

Undang-Undang Nomor 24 Tahun 2011 tentang Badan Penyelenggara Jaminan Sosial.

Peraturan Pemerintah Republik Indonesia Nomor 78 Tahun 2015 tentang Pengupahan.

Internet:

Mkn unand, Sejarah Notaris, Diakses dari https://mansyth.wordpress.com/tag/pengertian-kontrak/ diakses pada 18 Juli 2018.

http://www.sarjanaku.com/2012/12/ pengertian-perjanjian-kerja-definisi.html, diakses pada 18 Juli 2018.

http://artonang.blogspot.com/2014/ pengertian-dasar-ruang-lingkupdan.html diakses pada 18 Juli 2018.

http://legalakses.com/ perjanjian-kerja-untuk-waktu-tidak-tertentu-pkwtt/ diakses pada 19 Juli 2018. 